\title{
Effect of HLA-DPA1 alleles on chronic hepatitis B prognosis and treatment response
}

\author{
Seyma Katrinli, ${ }^{1}$ Feruze Yilmaz Enc, ${ }^{2}$ Kamil Ozdil, ${ }^{3}$ Oguzhan Ozturk, ${ }^{3}$ \\ Ilyas Tuncer, ${ }^{2}$ Gizem Dinler Doganay, ${ }^{1}$ Levent Doganay $^{3}$ \\ ${ }^{1}$ Department of Molecular Biology and Genetics, Istanbul Technical University, Istanbul, Turkey \\ 2Department of Gastroenterology, Goztepe Training and Research Hospital, Medeniyet University, Istanbul, Turkey \\ ${ }^{3}$ Department of Gastroenterology, Umraniye Training and Research Hospital, University of Medical Sciences, Istanbul, Turkey
}

\begin{abstract}
OBJECTIVE: Chronic hepatitis B (CHB) is a major health problem. The outcome of hepatitis B virus (HBV) infection is associated with variations in HLA-DPA1 alleles. The aim of this study was to investigate possible associations of HLA-DPA1 alleles with treatment response and with hepatitis B virus e antigen (HBeAg) seroconversion.

METHODS: Eight different HLA-DPA1 alleles from 246 CHB patients were genotyped by polymerase chain reaction with sequence-specific primers at high resolution to investigate the association of HLA-DPA1 alleles with treatment response, development of cirrhosis, HBeAg seroconversion, and disease reoccurrence upon HBeAg loss.

RESULTS: There was no significant association between HLA-DPA1 alleles and treatment response, development of cirrhosis, or HBeAg seroconversion. However, HLA-DPA1*04:01 allele was significantly more frequently found in patients who redeveloped disease upon $\mathrm{HBeAg}$ seroconversion ( $100 \%$ vs $36.8 \%$ : $\mathrm{p}=0.037$; Fisher's exact test).
\end{abstract}

CONCLUSION: HLA-DPA1*04:01 allele may be a risk factor for reoccurrence of CHB after HBeAg seroconversion. Keywords: Chronic hepatitis B; cirrhosis; HBeAg seroconversion; HLA-DPA1; treatment response.

$\mathrm{C}$ hronic hepatitis $\mathrm{B}(\mathrm{CHB})$ is a major global health issue, and despite national vaccination programs, between 350 million and 400 million people are infected with hepatitis $B$ virus (HBV) worldwide [1]. Chronic HBV infection results in liver fibrosis, which can further develop into cirrhosis or hepatocellular carcinoma, both of which are major causes of liver-related death [2]. Number of annual deaths due to consequences of $\mathrm{HBV}$ in- fection is estimated to be nearly 600000 worldwide [3]. In Turkey, $5 \%$ of population is hepatitis B surface antigen positive, and our country currently has medium endemicity profile for hepatitis B [4].

Development of chronic HBV infection is a complex process that involves various viral, environmental and genetic components, such as HBV genomic variability, host age, and sex, as well as concurrent infection with hepatitis $\mathrm{C}$ virus (HCV), hepatitis D

Received: November 29, 2016 Accepted: December 14, 2016 Online: January 25, 2017

Correspondence: Levent DOGANAY, MD. Saglik Bilimleri Universitesi, Umraniye Egitim ve Arastirma Hastanesi, Gastroenteroloji Klinigi, Elmalikent Mahallesi, Adem Yavuz Cad. No: 1, Umraniye, Istanbul, Turkey.

Tel: +90 216 - 6321818 e-mail: levent.doganay@ueh.gov.tr

(c) Copyright 2016 by Istanbul Northern Anatolian Association of Public Hospitals - Available online at www.kuzeyklinikleri.com 
virus, and human immunodeficiency virus (HIV) $[5,6,7,8]$. Segregation analysis and twin studies also suggest involvement of host genetic profile in development of chronicity in HBV infection $[9,10]$. Human leukocyte antigen (HLA) class II loci have been proposed as major genetic host sites associated with HBV infection $[11,12,13,14]$. HLA-restricted T lymphocytes and B lymphocytes in the humoral immune system are responsible for the generation of an accurate immunological response against the virus $[5,6]$. When this cytolytic immune reaction is inaccurate and nonselective in hepatocytes, instead of virus eradication, necroinflammation and liver fibrosis occur [15]. Genome-wide association studies (GWAS) have also demonstrated an association between HLA class II gene region and HBV chronicity $[16,17]$. A recent GWAS study reported specific association between HLA-DP locus and CHB in Japanese and Thai populations [18]. In the present study, 8 HLA-DPA1 polymorphisms in the Turkish population were screened in high resolution to investigate association between HLA-DPA1 polymorphisms and HBV treatment response, cirrhosis, hepatitis $\mathrm{B}$ e antigen ( $\mathrm{HBeAg}$ ) seroconversion, and recurrence of disease after $\mathrm{HBeAg}$ seroconversion.

\section{MATERIALS AND METHODS}

\section{Study group}

The present study, which was approved by the local ethics committee, included $246 \mathrm{CHB}$ patients who were followed-up at the hepatology clinic of Goztepe Teaching and Research Hospital between August 2005 and August 2010. Patient case notes were carefully reviewed, and demographic data, laboratory results, endoscopy results, virological parameters, biopsy scores, and treatment status details were analyzed. Patients with delta virus co-infection, $\mathrm{HCV}$, $\mathrm{HIV}$, liver disease other than HBV, patients receiving immunosuppressive treatment, and patients under age of 18 were not selected for the study. Demographic data of the patients is provided in Table 1.

\section{HLA-DPA1 genotyping}

In total, $5 \mathrm{~mL}$ of peripheral blood was collected from each patient and stored in ethylenediaminetetraace-
TABLE 1. Demographic data of patients

$\mathrm{n} \pm \mathrm{SD}$

(Min.-Max.)

$\begin{array}{lc}\begin{array}{l}\text { Gender } \\ \quad \text { Male }\end{array} & 152(61.8 \%) \\ \quad \text { Female } & 94(38.2 \%) \\ \text { Age } & \\ \text { Log DNA (IU/mL) } & 5.56 \pm 2.25 \\ \text { ALT (U/L) } & 92.03 \pm 100.72 \\ \text { AST (U/L) } & 61.51 \pm 59.32 \\ \text { HBeAg } & \\ \quad \text { Positive } & 56(22.8 \%) \\ \quad \text { Negative } & 190(77.2 \%) \\ \text { Cirrhosis } & \\ \quad \text { Presence } & 53(21.5 \%) \\ \quad \text { Absence } & 193(78.5 \%)\end{array}$

SD: Standard deviation; Min.: Minimum; Max.: Maximum; DNA: Deoxyribonucleic acid; ALT: Alanine transaminase; AST: Aspartate aminotransferase; HBeAg: Hepatitis B e antigen.

tic acid tubes at $-80^{\circ} \mathrm{C}$ until extraction of deoxyribonucleic acid (DNA). Genomic DNA was extracted from $1 \mathrm{~mL}$ of blood using Invitrogen PureLink Genomic DNA purification kit (Thermo Fischer Scientific, Inc., Waltham, MA, USA) according to manufacturer's instructions. Eight different HLA DPA1 alleles were screened by polymerase chain reaction with sequence-specific primers (PCR-SSP) at high resolution [19]. Primer sequences and PCR product lengths are listed in Table 2. Internal positive control primers were included in the reaction system to exclude false negatives. Internal control was 439 bp fragment of human growth hormone gene 1 (Forward primer:5'GCCTTCCCAACC ATTCCCTTA3', Reverse primer: 5'TCACGGATTTATGTTGTGTTTC3'). PCR was performed in $25 \mu \mathrm{L}$ reaction mixture containing 0.5 units of DreamTaq Green DNA Polymerase (Thermo Fisher Scientific, Inc., Waltham, MA, USA), 1 $\mathrm{mM}$ magnesium chloride, $0.8 \mathrm{mM}$ deoxynucleotide triphosphates, $0.2 \mathrm{mM}$ primers, and $0.05 \mathrm{mM}$ internal control primers. PCR amplification was achieved with initial denaturation at $94^{\circ} \mathrm{C}$ for 2 minutes followed by 30 amplification cycles. First 10 cycles consisted of denaturation at $94^{\circ} \mathrm{C}$ for 10 


\begin{tabular}{|c|c|c|}
\hline DPA1 allele & Primer & PCR product \\
\hline \multirow[t]{2}{*}{ *01:03/03:01 } & F: 5'GGGAGTTTATGTTTGAATTTGATGAA ${ }^{3^{\prime}}$ & $209 \mathrm{bp}$ \\
\hline & R: ${ }^{\prime}$ AGATAGGGCGTTACCGTTGG ${ }^{3}$ & \\
\hline \multirow[t]{2}{*}{ *01:03/01:04 } & F: ${ }^{5^{\prime}}$ ATGCCGCGTTTGTACAGACG ${ }^{3}$ & 242 bp \\
\hline & R: ${ }^{\prime}$ AGATAGGGCGTTACCGTTGGT T' & \\
\hline \multirow[t]{2}{*}{$* 01: 04$} & F: 5'TCTCTACTGTCTTTATGCAGCGG'3' & 119 bp \\
\hline & R: 5'GATCCACATAGAACATCTCATCG ${ }^{\prime}$ & \\
\hline \multirow[t]{2}{*}{$* 02: 01: 01 / 02: 01: 02$} & F: 5'GACCATGTGTCAACTTATGCCGC ${ }^{3 \prime}$ & 108 bp \\
\hline & R: 5'CTTTTAATCCAGATCCACATAGAACTG ${ }^{3}$ & \\
\hline \multirow[t]{2}{*}{ *02:02:01/02:02:02 } & F: 5'GACCATGTGTCAACTTATGCCA ${ }^{3^{\prime}}$ & $103 \mathrm{bp}$ \\
\hline & R: ${ }^{5}$ CTTGTCCAGATCCACATAGAACTG ${ }^{3}$ & \\
\hline \multirow[t]{2}{*}{$* 03: 01$} & F: 5'GACCATGTGTCAACTTATGCCAT T' & 258 bp \\
\hline & R: ${ }^{\prime}$ AGATAGGGCGTTACCGTTGGT ${ }^{3}$ & \\
\hline \multirow[t]{2}{*}{ *04:01 } & F: 5'GCGTTTGTACAGACGCATAGAA ${ }^{3{ }^{\prime}}$ & $207 \mathrm{bp}$ \\
\hline & R: ${ }^{\prime}$ GTGGTTGGAACGCTGGATAGC ${ }^{3}$ & \\
\hline \multirow[t]{2}{*}{ *02:01:01 } & F: ${ }^{5^{\prime}}$ ATGCCGCGTTTGTACAGACC ${ }^{3}$ & $109 \mathrm{bp}$ \\
\hline & R: ${ }^{\prime}$ AGATGCCAGACGGTCTCCTTT' ${ }^{3}$ & \\
\hline \multirow[t]{2}{*}{$* 02: 01: 02$} & F: ${ }^{5}$ TATGCCGCGTTTGTACACACG ${ }^{\prime}$ & $110 \mathrm{bp}$ \\
\hline & R: ${ }^{5}$ AGATGCCAGACGGTCTCCTTT' ${ }^{3 \prime}$ & \\
\hline \multirow[t]{2}{*}{$* 02: 02: 01$} & F: 5'GACCATGTGTCAACTTATGCCAT ${ }^{3 \prime}$ & 122 bp \\
\hline & R: ${ }^{5}$ TGCCAGACGGTCTCCTTCTTA ${ }^{3^{\prime}}$ & \\
\hline \multirow[t]{2}{*}{$* 02: 02: 01 / 03: 01$} & F: 5'GACCATGTGTCAACTTATGCCA ${ }^{3^{\prime}}$ & $121 \mathrm{bp}$ \\
\hline & R: ${ }^{5}$ GCCAGACGGTCTCCTTCTTG ${ }^{3}$ & \\
\hline
\end{tabular}

PCR: polymerase chain reaction.

seconds followed by combined annealing-extension step at $65^{\circ} \mathrm{C}$ for 60 seconds. Remaining 20 cycles consisted of denaturation at $94^{\circ} \mathrm{C}$ for 10 seconds, annealing at $61^{\circ} \mathrm{C}$ for 50 seconds, and extension at $72^{\circ} \mathrm{C}$ for 30 seconds. After amplification, $10 \mu \mathrm{L}$ of PCR products were loaded onto $2 \%$ agarose gel and stained with SYBR Green I Nucleic Acid Gel Stain (Thermo Fisher Scientific, Inc, Waltham, MA, USA). Upon visualization under ultraviolet light, DPA1 allele types were determined according to presence or absence of a PCR product of corresponding length.

\section{Statistical analysis}

Statistical analyses were performed to evaluate differences between groups: patients with and without good treatment response to standard antiviral drugs, patients with and without good treatment response to nucleotide analogs, patients with and without good treatment response to interferon, patients with and without cirrhosis, patients with and without $\mathrm{HBeAg}$ seroconversion, and patients with and without disease progression after $\mathrm{HBeAg}$ seroconversion. For these analyses, $2 \times 2$ contingency tables and chi-square test were used. If the sample size was small, Fisher's exact test was applied.

For all analyses, SPSS Statistics 21 (IBM Corp., Armonk, NY, USA) was used; double-sided p values were calculated, and $\mathrm{p}<0.05$ was considered statistically significant.

\section{RESULTS}

CHB patients were grouped and analyzed according to their treatment response to standard antiviral drugs, nucleotide analogs or interferon, presence of 


\begin{tabular}{lcc} 
TABLE 3. Number of patients in each study group & \\
\hline Study group & & $\begin{array}{c}\text { Number of } \\
\text { patients }\end{array}$ \\
\hline Treatment response to all antivirals & Yes & 93 \\
Treatment response to nucleotide analogs & No & 99 \\
& Yes & 71 \\
Treatment response to interferon & No & 73 \\
Cirrhosis & Yes & 69 \\
& No & 14 \\
HBeAg seroconversion & Present & 53 \\
& Absent & 193 \\
Recurrence of disease after HBeAg seroconversion & Present & 23 \\
& Absent & 34 \\
& Present & 11 \\
\hline
\end{tabular}

HBeAg: Hepatitis B e antigen.

$\begin{aligned} & \text { TABLE 4. Frequency of DPA1 alleles among chronic } \\
& \text { hepatitis } B \text { patients }(n=246)\end{aligned}$
\begin{tabular}{lcc} 
DPA1 alleles & \multicolumn{2}{c}{ Frequency $(n=246)$} \\
\cline { 2 - 3 } & $n$ & $\%$ \\
\hline DPA $1 * 01: 03$ & 114 & 46.3 \\
DPA $1 * 01: 04$ & 46 & 18.7 \\
DPA $1 * 03: 01$ & 190 & 77.2 \\
DPA $1 * 04: 01$ & 55 & 22.4 \\
DPA $1 * 02: 01: 01$ & 27 & 11.0 \\
DPA $1 * 02: 01: 02$ & 31 & 12.6 \\
DPA $1 * 02: 02: 01$ & 10 & 4.1 \\
DPA $1 * 02: 02: 02$ & 9 & 3.7
\end{tabular}

cirrhosis, $\mathrm{HBeAg}$ seroconversion, and recurrence of disease after $\mathrm{HBeAg}$ seroconversion. Number of patients in each group can be seen in Table 3 and frequency of all DPA1 alleles among all patients $(\mathrm{n}=246)$ is listed in Table 4.

No significant association was observed between HLA DPA1 alleles and patients with or without cirrhosis (Table 5). Neither was there significant association between HLA DPA1 alleles and patients with or without $\mathrm{HBeAg}$ seroconversion. In addition, HLA DPA1 alleles were not found to be associated with treatment response to standard antiviral drugs (Table 6), nucleotide analogs, or interferon. However, when recurrence of disease after seroconversion was analyzed, HLA DPA $1^{*} 04: 01$ allele was significantly more frequently found in patient $\mathrm{CHB}$ group with recurrence vs patients with inactive disease $(100 \%$ vs $36.8 \% ; p=0.037$; Fisher's exact test) (Table 7).

\section{DISCUSSION}

$\mathrm{CHB}$ treatment is a challenging issue. In addition to viral factors, several host immune factors participate in drug resistance, $\mathrm{HBeAg}$ seroconversion, and reoccurrence of the disease. Since HLA-DPA1 and -DPB1 are less polymorphic than HLA-DR or -DQ, and HLA-DP cell surface expression levels are also likely to be lower, HLA-DP region was not thought to have as much clinical impact as other HLA alleles [20, 21]. However, recent GWAS studies have shown that HLA-DP region is associated with both protection against $\mathrm{CHB}$ and viral clearance $[16,17,18]$.

HLA-DPA1 molecules, which are HLA class II molecules, are responsible for antigen presentation 
TABLE 5. Frequency of HLA DPA1 alleles in patients with and without cirrhosis

\begin{tabular}{|c|c|c|c|c|c|}
\hline \multirow[t]{2}{*}{ DPA1 alleles } & \multicolumn{2}{|c|}{$\begin{array}{l}\text { Cirrhotic patient group } \\
\qquad(\mathrm{n}=53)\end{array}$} & \multicolumn{2}{|c|}{$\begin{array}{l}\text { Non-cirrhotic patient group } \\
\qquad(\mathrm{n}=193)\end{array}$} & \multirow[t]{2}{*}{$\mathrm{p}$} \\
\hline & $\mathrm{n}$ & $\%$ & $\mathrm{n}$ & $\%$ & \\
\hline DPA $1 * 01: 03$ & 29 & 54.7 & 85 & 44.0 & 0.167 \\
\hline DPA1*01:04 & 9 & 17.0 & 37 & 19.2 & 0.717 \\
\hline DPA1*03:01 & 39 & 73.6 & 151 & 78.2 & 0.474 \\
\hline DPA $1 * 04: 01$ & 7 & 13.2 & 48 & 24.9 & 0.071 \\
\hline DPA1*02:01:01 & 6 & 11.3 & 21 & 10.9 & 0.928 \\
\hline DPA1*02:01:02 & 6 & 11.3 & 25 & 13.0 & 0.751 \\
\hline DPA1*02:02:01 & 3 & 5.7 & 7 & 3.6 & 0.507 \\
\hline DPA $1 * 02: 02: 02$ & 3 & 5.7 & 6 & 3.1 & 0.381 \\
\hline
\end{tabular}

TABLE 6. Distribution of HLA DPA1 alleles according to treatment response

\begin{tabular}{|c|c|c|c|c|c|}
\hline \multirow[t]{2}{*}{ DPA1 alleles } & \multicolumn{2}{|c|}{$\begin{array}{l}\text { Patients with treatment } \\
\text { response }(n=99)\end{array}$} & \multicolumn{2}{|c|}{$\begin{array}{l}\text { Patients without treatment } \\
\text { response }(n=93)\end{array}$} & \multirow[t]{2}{*}{$\mathrm{p}$} \\
\hline & $\mathrm{n}$ & $\%$ & $\mathrm{n}$ & $\%$ & \\
\hline DPA1*01:03 & 49 & 49.5 & 40 & 43.0 & 0.368 \\
\hline DPA $1 * 01: 04$ & 19 & 19.2 & 18 & 194 & 0.977 \\
\hline DPA1*03:01 & 72 & 72.7 & 73 & 78.5 & 0.353 \\
\hline DPA1*04:01 & 16 & 16.2 & 22 & 23.7 & 0.193 \\
\hline DPA1*02:01:01 & 13 & 13.1 & 11 & 11.8 & 0.785 \\
\hline DPA $1 * 02: 01: 02$ & 12 & 12.1 & 10 & 10.8 & 0.766 \\
\hline DPA1*02:02:01 & 6 & 6.1 & 3 & 3.2 & 0.353 \\
\hline DPA $1 * 02: 02: 02$ & 5 & 5.1 & 3 & 3.2 & 0.527 \\
\hline
\end{tabular}

TABLE 7. Frequency of HLA DPA $1 * 04: 01$ allele in hepatitis $B$ e antigen seroconverted group with and without disease recurrence

\begin{tabular}{|c|c|c|c|c|}
\hline & \multicolumn{2}{|c|}{$\begin{array}{l}\text { Patients with disease recurrence after } \\
\text { HBeAg seroconversion }\end{array}$} & \multicolumn{2}{|c|}{$\begin{array}{c}\text { Patients with inactive disease after } \\
\text { HBeAg seroconversion }\end{array}$} \\
\hline & $\mathrm{n}$ & $\%$ & $\mathrm{n}$ & $\%$ \\
\hline HLA DPA $1 * 04: 01$ carrier & 4 & 100 & 0 & 0 \\
\hline HLA DPA $1 * 04: 01$ non- carrier & 7 & 36.8 & 12 & 63.2 \\
\hline
\end{tabular}

HBeAg: Hepatitis B e antigen. $p=0.037$ according to Fisher's exact test.

to CD4+ T helper cells. Since T cell helper response is critical for HBV clearance, there is a direct link between HBV clearance and increased CD4+ T cells response [22, 23]. Antigen-binding sites of HLADP molecules, which play a crucial role in the physical binding of peptides and subsequent recognition 
by T-cells, are highly polymorphic $[24,25]$. Therefore, diversity of HLA-DPA1 alleles due to variations in the HLA-DP coding regions is a key factor in antigen presentation and hence, viral clearance.

Recent studies demonstrated that HLA-DPA1 SNPs rs3077 and rs9277378, which are located in the 3'UTR and $2 \mathrm{~Kb}$ upstream intronic site, respectively, are associated with spontaneously resolved HBV infection [26, 27] and chronicity of $\mathrm{HBV}[28$, 29]. In this study, no significant association between HLA-DPA1 alleles and $\mathrm{HBeAg}$ seroconversion was found. However, we observed higher frequency of HLA-DPA $1^{*} 04: 01$ allele in patients with active disease vs inactive disease after $\mathrm{HBeAg}$ seroconversion (100\% vs $36.8 \%$; $p=0.037$; Fisher's exact test), thus showing an association between HLA-DPA1 and recurrence of disease after $\mathrm{HBeAg}$ loss. Lack of association between HLA-DPA1 alleles and $\mathrm{HBeAg}$ seroconversion has also been stated in the literature [30]. However, HLA-DPA1 alleles were shown to be associated with $\mathrm{HBeAg}$ loss, anti-HBe seroconversion, and HBV DNA level suppression in $\mathrm{HBeAg}$ seropositive $\mathrm{CHB}$ patients upon interferon alpha or pegylated interferon treatment [31]. In conclusion, presence of HLA-DPA $1^{*} 04: 01$ allele may be a risk factor for recurrence of the disease upon $\mathrm{HBeAg}$ seroconversion, and thus may be a potential biomarker to predict patients in need of prolonged antiviral therapy. Nonetheless, a larger cohort is required to validate this finding.

\section{Conflict of Interest: None declared.}

Financial Disclosure: Sources of funding for this study were Istanbul Technical University internal funds and Umraniye Education and Research Hospital internal funds.

Authorship contributions: Concept - K.Ö., İ.T., G.D.D., L.D.; Design - K.Ö., İ.T., G.D.D., L.D.; Supervision - K.Ö., İ.T., G.D.D., L.D.; Materials - K.Ö., İ.T., G.D.D., L.D.; Data collection \&/or processing - Ş.K., O.Ö., F.Y.E.; Analysis and/or interpretation Ş.K., G.D.D., L.D.; Literature search - Ş.K., O.Ö.; Writing - Ş.K., O.Ö., G.D.D., L.D.; Critical review - K.Ö., İ.T., G.D.D., L.D.

\section{REFERENCES}

1. Lavanchy D. Hepatitis B virus epidemiology, disease burden, treatment, and current and emerging prevention and control measures. J Viral Hepat 2004;11:97-107. Crossre.

2. Calvaruso V, Craxi A. Fibrosis in chronic viral hepatitis. Best practice $\&$ research Clinical gastroenterology 2011;25:219-30.

3. Goldstein ST, Zhou F, Hadler SC, Bell BP, Mast EE, Margolis HS. A mathematical model to estimate global hepatitis $B$ disease burden and vaccination impact. Int J Epidemiol 2005;34:132939. Crossret

4. Alacacioglu A, Somali I, Simsek I, Astarcioglu I, Ozkan M, Camci C, et al. Epidemiology and survival of hepatocellular carcinoma in Turkey: outcome of multicenter study. Jpn J Clin Oncol 2008;38:683-8. Crossre

5. Chu CJ, Lok AS. Clinical significance of hepatitis B virus genotypes. Hepatology 2002;35:1274-6. Crossret

6. Wang FS. Current status and prospects of studies on human genetic alleles associated with hepatitis B virus infection. World journal of gastroenterology, WJG 2003;9:641-4. Crossre

7. Thursz M. Genetic susceptibility in chronic viral hepatitis. Antivir Res 2001;52:113-6. Crossre

8. Frodsham AJ, Hill AVS. Genetics of infectious diseases. Human Molecular Genetics 2004;13:187-94. Crossree

9. Hann HWL, Kim CY, London WT, Whitford P, Blumberg BS. Hepatitis-B Virus and Primary Hepatocellular-Carcinoma - Family Studies in Korea. Int J Cancer 1982;30:47-51. Crossref

10. Lin TM, Chen CJ, Wu MM, Yang CS, Chen JS, Lin CC, et al. Hepatitis-B Virus Markers in Chinese Twins. Anticancer Res 1989;9:737-41.

11. Thursz MR, Kwiatkowski D, Allsopp CE, Greenwood BM, Thomas HC, Hill AV. Association between an MHC class II allele and clearance of hepatitis B virus in the Gambia. The New England journal of medicine 1995;332:1065-9. Crossret

12. Hohler T, Gerken G, Notghi A, Lubjuhn R, Taheri H, Protzer U, et al. HLA-DRB1*1301 and ${ }^{*} 1302$ protect against chronic hepatitis B. Journal of hepatology 1997;26:503-7. Crossree

13. Ahn SH, Han KH, Park JY, Lee CK, Kang SW, Chon CY, et al. Association between hepatitis $\mathrm{B}$ virus infection and HLA-DR type in Korea. Hepatology 2000;31:1371-3. Crossre

14. Kummee P, Tangkijvanich P, Poovorawan Y, Hirankarn N. Association of HLA-DRB $1^{\star} 13$ and TNF-alpha gene polymorphisms with clearance of chronic hepatitis B infection and risk of hepatocellular carcinoma in Thai population. Journal of viral hepatitis 2007;14:841-8.

15. Guo XC, Wu YQ. A review: progress of prevention and control on viral hepatitis in China. Biomed Environ Sci 1999;12:22732.

16. Mbarek H, Ochi H, Urabe Y, Kumar V, Kubo M, Hosono N, et al. A genome-wide association study of chronic hepatitis B identified novel risk locus in a Japanese population. Hum Mol Genet. 2011;20:3884-92. Crossret

17. Nishida N, Sawai H, Matsuura K, Sugiyama M, Ahn SH, Park JY, et al. Genome-wide association study confirming association of HLA-DP with protection against chronic hepatitis B and viral clearance in Japanese and Korean. PLoS One 2012;7:39175.

18. Kamatani Y, Wattanapokayakit S, Ochi H, Kawaguchi T, Takahashi A, Hosono N, et al. A genome-wide association study identifies variants in the HLA-DP locus associated with chronic 
hepatitis B in Asians. Nat Genet 2009;41:591-5. Crossre

19. Aldener-Cannava A, Olerup O. HLA-DPA1 typing by PCR amplification with sequence-specific primers (PCR-SSP) and distribution of DPA1 alleles in Caucasian, African and Oriental populations. Tissue antigens 1996;48:153-60. Crossref

20. Edwards JA, Durant BM, Jones DB, Evans PR, Smith JL. Differential expression of HLA class II antigens in fetal human spleen: relationship of HLA-DP, DQ, and DR to immunoglobulin expression. J Immunol 1986;137:490-7.

21. Guardiola J, Maffei A. Control of MHC class II gene expression in autoimmune, infectious, and neoplastic diseases. Crit Rev Immunol 1993;13:247-68.

22. Penna A, Del Prete G, Cavalli A, Bertoletti A, D’Elios MM, Sorrentino $\mathrm{R}$, et al. Predominant $\mathrm{T}$-helper 1 cytokine profile of hepatitis $B$ virus nucleocapsid-specific $T$ cells in acute self-limited hepatitis B. Hepatology 1997;25:1022-7. Crossre.

23. Urbani S, Boni C, Amadei B, Fisicaro P, Cerioni S, Valli MA, et al. Acute phase HBV-specific $\mathrm{T}$ cell responses associated with $\mathrm{HBV}$ persistence after $\mathrm{HBV} / \mathrm{HCV}$ coinfection. Hepatology 2005;41:826-31. Crossre

24. Fontenot AP, Torres M, Marshall WH, Newman LS, Kotzin BL. Beryllium presentation to CD4+ T cells underlies diseasesusceptibility HLA-DP alleles in chronic beryllium disease. Proceedings of the National Academy of Sciences of the United States of America 2000;97:12717-22. Crossre

25. Diaz G, Amicosante M, Jaraquemada D, Butler RH, Guillen MV, Sanchez M, et al. Functional analysis of HLA-DP poly- morphism: a crucial role for DPbeta residues 9, 11, 35, 55, 56, 69 and 84-87 in T cell allorecognition and peptide binding. Int Immunol 2003;15:565-76

26. Wasityastuti W, Yano Y, Ratnasari N, Triyono T, Triwikatmani $\mathrm{C}$, Indrarti F, et al. Protective effects of HLA-DPA1/DPB1 variants against Hepatitis B virus infection in an Indonesian population. Infect Genet Evol 2016;41:177-84.

27. Posuwan N, Payungporn S, Tangkijvanich P, Ogawa S, Murakami $S$, Iijima $S$, et al. Genetic association of human leukocyte antigens with chronicity or resolution of hepatitis B infection in thai population. PLoS One 2014;9:86007.

28. Wong DK, Watanabe T, Tanaka Y, Seto WK, Lee CK, Fung J, et al. Role of HLA-DP polymorphisms on chronicity and disease activity of hepatitis B infection in Southern Chinese. PLoS One 2013;8:66920. Crossree

29. An P, Winkler C, Guan L, O'Brien SJ, Zeng Z, Consortium HBVS. A common HLA-DPA1 variant is a major determinant of hepatitis B virus clearance in Han Chinese. J Infect Dis 2011;203:943-7.

30. Komatsu H, Murakami J, Inui A, Tsunoda T, Sogo T, Fujisawa T. Association between single-nucleotide polymorphisms and early spontaneous hepatitis B virus e antigen seroconversion in children. BMC Res Notes 2014;7:789. Crossee

31. Cheng L, Sun X, Tan S, Tan W, Dan Y, Zhou Y, et al. Effect of HLA-DP and IL28B gene polymorphisms on response to interferon treatment in hepatitis $\mathrm{B}$ e-antigen seropositive chronic hepatitis B patients. Hepatol Res 2014;44:1000-7. Crossre] 